\title{
Testicular epidermoid cysts
}

\section{Okwudili Emmanuel Muoka, Nazeer Dahar}

Department of Urology, Lincoln County Hospital, Lincoln, UK

\section{Correspondence to} Okwudili Emmanuel Muoka, odimuoka@yahoo.com

\section{DESCRIPTION}

A 26-year-old man was referred by his general practitioner as an urgent referral based on a 2-week history of a hard right testicular mass. There was no history of trauma, sexually transmitted infections or previous testicular surgery. On examination, a hard $2 \mathrm{~cm}$ irregular mass was palpable at the lower pole of the right testis. It was separate from the epididymis and scrotal wall. There was no clinically detectable hydrocoele. The left testis, epididymis and cord structures were normal. His serum $\alpha$-feto protein , $\beta$-human chorionic gonadotropin and lactic dehydrogenase were normal. $\mathrm{He}$ had an ultrasound scan of the testis which revealed a $20 \mathrm{~mm}$ well-circumscribed ring-shaped intratesticular lesion in the lower pole of the testis with alternate hypoechoic and echogenic layers (onion skin appearance) and normal surrounding testis

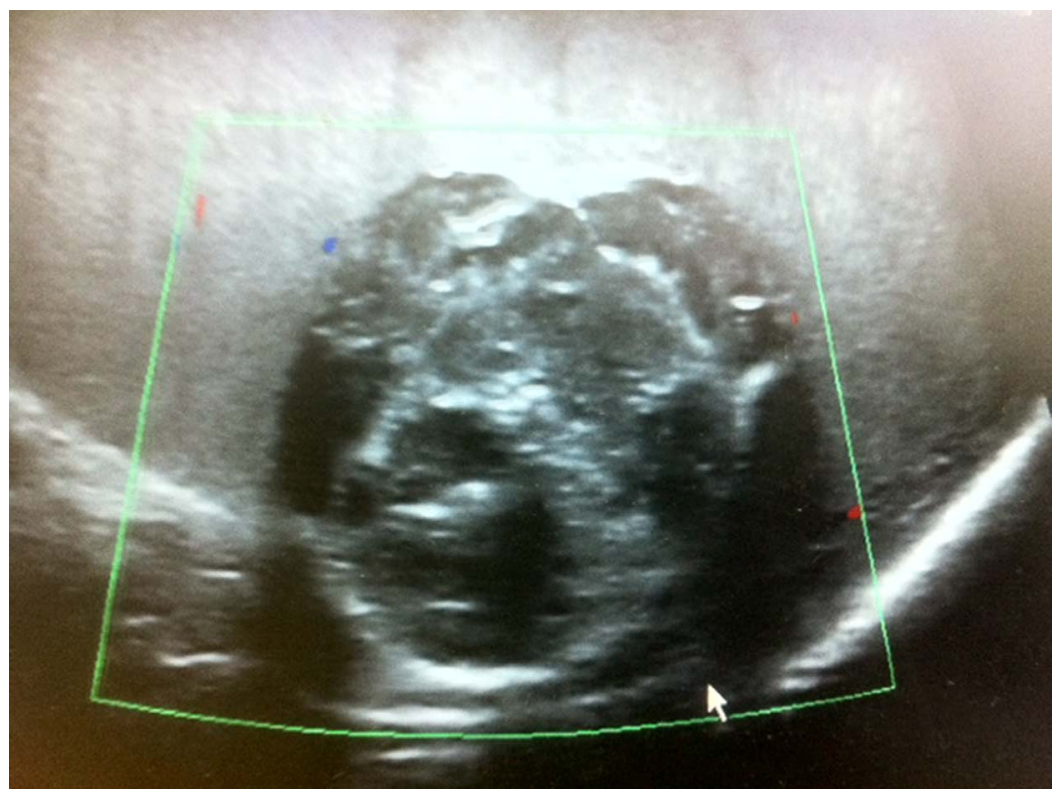

Figure 1 Hypoechoic ring-shaped lesion with no evidence of Doppler flow.

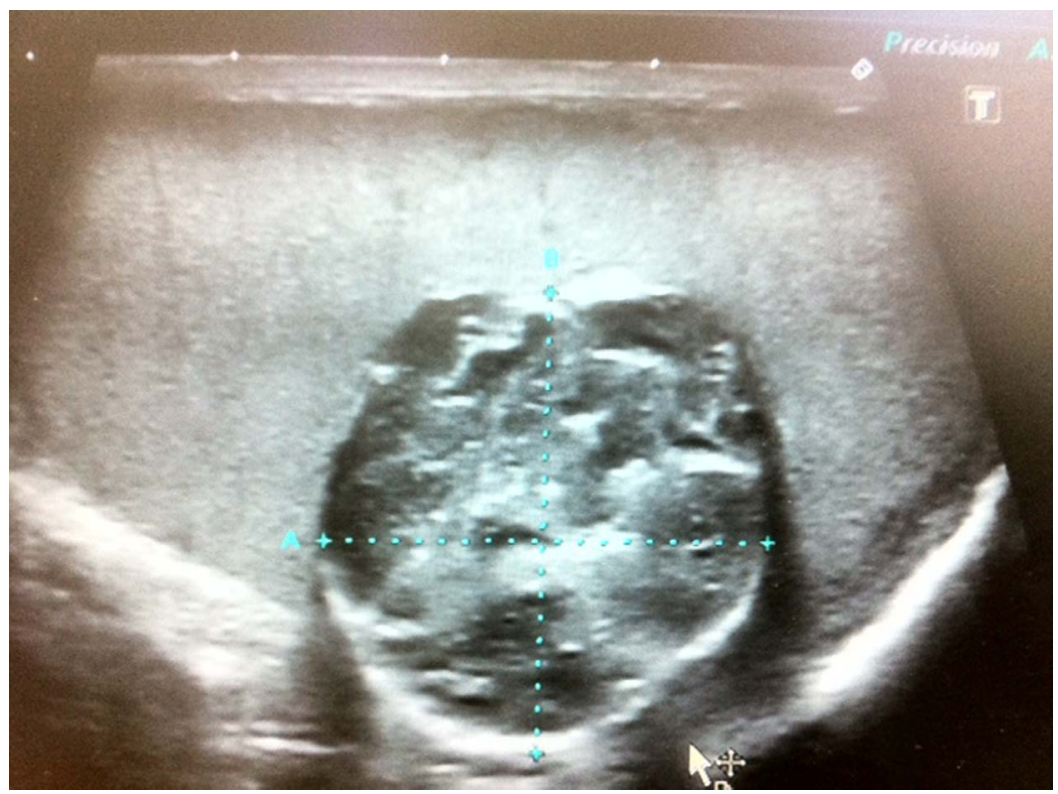

cite: Muoka $\mathrm{OE}$ Dahar N. BMJ Case Rep Published online: [please include Day Month Year] doi:10.1136/bcr-2013009103

Figure 2 A well-circumscribed ring-shaped intratesticular lesion in the lower pole of the testis with alternate hypoechoic and echogenic layers (onion skin appearance) and normal surrounding testis tissue in keeping with an epidermoid cyst. 
tissue (figure 1). ${ }^{1-3}$ There was no evidence of Doppler flow within the lesion and the lower pole of the right testis (figure 2). There was no hydrocoele or other abnormalities. The case was discussed at our multidisciplinary team meeting and the impression was that this could be an epidermoid cyst but a testicular malignancy was also likely. As such he was offered a right radical orchidectomy or referral to another centre offering frozen section for exploration. He opted for a right radical orchidectomy with insertion of a testicular prosthesis. The histology of the specimen was eventually reported as an epidermoid cyst of the testis.

\section{Learning points}

It is possible to make a diagnosis of an epidermoid cyst from ultrasound imaging.

- If the diagnosis is in doubt then the use of frozen section at time of surgery should be considered.
Contributors OEM and ND were involved in the conception and writing of the article and also approved the final draft.

Competing interests None.

Patient consent Obtained.

Provenance and peer review Not commissioned; externally peer reviewed.

\section{REFERENCES}

1 Price EB Jr. Epidermoid cyst of the testis: a clinical and pathological analysis of 69 cases from the testicular tumour registry. J Urol 1969;102:708-13.

2 Loya AG, Said JW, Grant EG. Epidermoid cyst of the testis: radiologic-pathologic correlation. Radiographics 2004;24(Suppl 1):S243-6.

3 Dogra VS, Cottlieb RH, Rubens DJ, et al. Benign intratesticular cystic lesions: US features. RadioGraphics 2001;21:5273-81.

Copyright 2013 BMJ Publishing Group. All rights reserved. For permission to reuse any of this content visit http://group.bmj.com/group/rights-licensing/permissions.

BMJ Case Report Fellows may re-use this article for personal use and teaching without any further permission.

Become a Fellow of BMJ Case Reports today and you can:

- Submit as many cases as you like

- Enjoy fast sympathetic peer review and rapid publication of accepted articles

- Access all the published articles

- Re-use any of the published material for personal use and teaching without further permission

For information on Institutional Fellowships contact consortiasales@bmjgroup.com

Visit casereports.bmj.com for more articles like this and to become a Fellow 